\title{
4,4'-ビスージメチルアミノ-チオベンゾフェノンによる 水道水中の残留塩素の定量
}

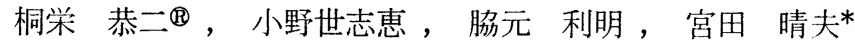

(1982 年 4 月 19 日受理)

\begin{abstract}
水道水中の残留塩素は，4,4'-ビスージメチルアミノーチオベンゾフェノンを定量的に酸化し，青色の キノイド型陽イオンを生成する。 その $650 \mathrm{~nm}$ に㧍ける吸光度を測定して残留塩素量を吸光光度法で 定量した.キノイド型陽イオンのモル吸光係数は, $7.65 \times 10^{4} \mathrm{dm}^{3} \mathrm{~mol}^{-1} \mathrm{~cm}^{-1}$ であった. 又, 水道水 中に共存する各種イオンは， $\left(5 \times 10^{-3} \sim 5 \times 10^{-5}\right) \mathrm{M}$ の範囲内では妨害が認められなかった。

更に, この吸光光度法をフローインジェクション分析法に応用した結果, 多数の試料の残留塩素を短 時間に定量することが可能になった。
\end{abstract}

\section{1 緒言}

水道水中の 残留塩素の定量には, オルト・トリジン 法, $N, N^{\prime}$-ジェチルーpーフェニレンジアミン法などが用 いられている1).

これらの定量方法はいずれす比色法であるが，標準比 色列の作製などの煩雑さやその経時变化，目視法などの 短所が認められる.

Feig12) らは式（1）に示すよらに，らすい塩素水を $4,4^{\prime}$-ビスージメチルアミノーチオベンゾフェノンのベン ゼン溶液と振り混ぜると, 水溶性の深青色のキノイド型 陽イオンが生成することを利用して遊離塩素を検出して いる.

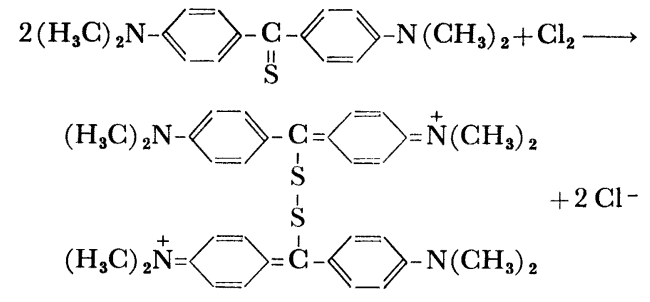

著者らは，この反応に注目し，水道水に $4,4^{\prime}$-ビス一 ジメチルアミノーチオベンゾフェノンのプロパノール溶 液を加えて発色させ，吸光光度法により $1 \mathrm{ppm}$ 又はそ れ以下の残留塩素を簡単に定量する方法を確立した。

* 岡山大学理学部化学教室 : 岡山県岡山市津島中 3$1-1$
又，この反応をフローインジェクション分析法に応用 を試み，良好な結果が得られたので併せて報告する。

\section{2 試薬及び装置}

\section{1 試 薬}

4,4'-ビスージメチルアミノーチオベンゾフェノン溶液： 氷酶酸から再結晶した $4,4^{\prime}$-ビスージメチルフミノーチオ ベンゾフェノン $4 \mathrm{mg}$, 濃塩酸 $0.5 \mathrm{ml}$ をプロパノール $100 \mathrm{ml}$ に加えて溶解する.

次亜塩素酸標準溶液: 市販 $5 \%$ 次亜塩素酸ナトリウ ム溶液 $2 \mathrm{ml}$ に $1 \mathrm{M}$ 酶酸 $40 \mathrm{ml}$ とヨウ化カリウム 1.3 $\mathrm{g}$ を加元, 遊離したヨウ素をあらかじめ標定した $0.1 \mathrm{~N}$ チオ硫酸ナトリウムで滴定した ${ }^{3)}$ 。指示薬として, デン プン溶液を用いた。 その結果, 次亜塩素酸の溶液は 1.30 $\mathrm{N}$ であった。この溶液を 100 倍に希釈して暗所に保存 し，使用の都度これを更に 250 倍に希釈して標準溶液 $(1.85 \mathrm{ppm})$ として用いた。酢酸・酿酸ナトリウム䌅衙 溶液 : $0.2 \mathrm{M}$ 酶酸及び $0.2 \mathrm{M}$ 酷酸ナトリウムを混合し, $\mathrm{pH}$ メーターで $\mathrm{pH} 4$ にする.

\section{2 装 置}

日立自記分光光度計 EPS-3 型, 島津分光光度計 UV100 型を用い，10 mm ガラスセルを使用した．日立一堀

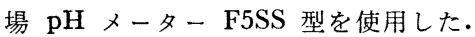

\section{3 定量方法}

$25 \mathrm{ml}$ 共栓付き試験管に水道水 $\left(\mathrm{Cl}_{2}\right.$ として $1.8 \mathrm{ppm}$ 以下) $10 \mathrm{ml}$ を採り, $0.2 \mathrm{M}$ 酶酸緩衝溶液 $1 \mathrm{ml}, 4,4^{\prime}$ ビスージィチルアミノーチオベンジフェノン溶液 $5 \mathrm{ml}$ を 加え, 手で数十回振り混ぜ, 10 分間放置後 $650 \mathrm{~nm}$ K 
おける吸光度を測定する．検量線から残留塩素を定量す る.

\section{4 実験結果及び考察}

\section{1 吸収曲線}

上記定量方法に従って描いた吸収曲線を Fig. 1 亿示 す. $650 \mathrm{~nm}$ に極大吸収を示し，その波長における空試 験值は 0.02 程度である。

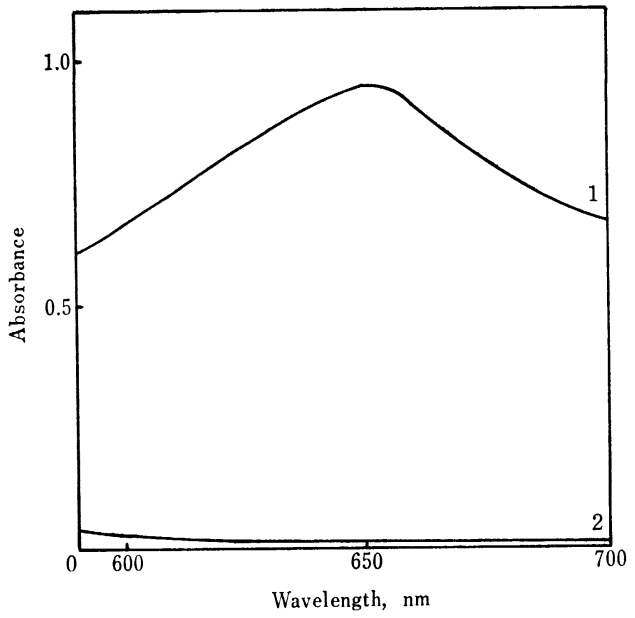

Fig. 1 Absorption spectra of 4, 4'-Bis-dimethylamino-thiobenzophenone

1 : Sample $\left(2 \times 10^{-5} \mathrm{M}\right) ; 2$ : Blank

\section{2 試薬濃度の影響}

然 $(2.5 \sim 6.0) \times 10^{-3} \%(\mathrm{w} / \mathrm{v})$ の 4,4'-ビスージメチルア ミノーチオベンゾフェノン溶液を作り，前記定量方法に 従って $1.8 \mathrm{ppmCl}_{2}$ 溶液について $650 \mathrm{~nm}$ に打ける吸光 度を測った. $3.5 \times 10^{-3} \%(\mathrm{w} / \mathrm{v})$ 以上で一定の吸光度を 示したので， $4 \times 10^{-3} \%(\mathrm{w} / \mathrm{v}) \quad$ の 4,4'-ビスージメチル アミノーチオベンゾフェノン溶液を用いることにした。

\section{3 pH の影響}

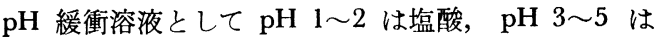
$0.2 \mathrm{M}$ 酶酸緩衝溶液， $\mathrm{pH}$ 6 8 は $0.2 \mathrm{M}$ リン酸緩衝溶 液を用いた．その結果を Fig. 2 亿示す．その結果, $\mathrm{pH}$ $3.5 \sim 4.0$ の間で最高一定值を示したので，0.2 M 酢酸 緩衝溶液を用いて $\mathrm{pH} 4$ で測定した。

\section{4 反応後の放置時間}

定量操作に従い, 反応後の時間による吸光度の変化を 追跡した。その結果，吸光度は時間とともに徐々に減少

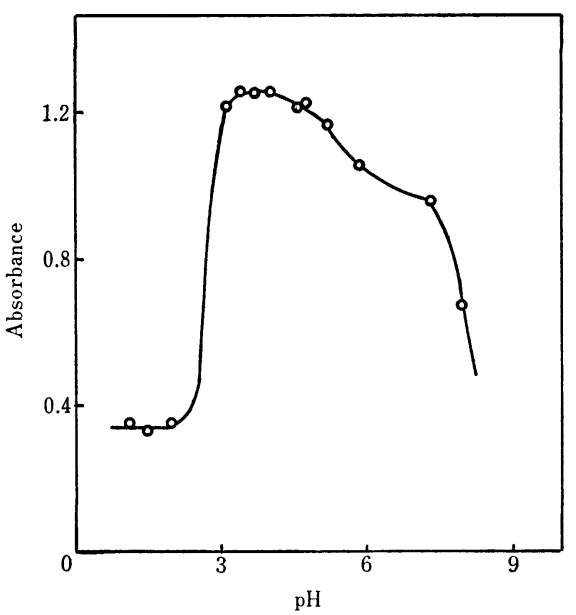

Fig. 2 Effect of $\mathrm{pH}$ on absorbance $1.8 \mathrm{ppm} \mathrm{Cl}_{2}$

を示したので，反応後 10 分における吸光度を測定する ことにした。

\section{5 検量線}

定量操作に従い, $0 \sim 2.6 \times 10^{-5} \mathrm{M}$ 次亜塩素酸ナトリ ウム $10 \mathrm{ml}$ を用い，吸光度から検量線を作成した. 原 点を通る直線となり，全容 $16 \mathrm{ml}$ 中のモル吸光係数は $7.65 \times 10^{4} \mathrm{dm}^{3} \mathrm{~mol}^{-1} \mathrm{~cm}^{-1}$ であった。

\section{6 共存イオンの影響}

遊離塩素として $0.9 \mathrm{ppm}$ を含を蒸留水に, 各種イオ ンを共存させて，その吸光度が $0.9 \mathrm{ppm}$ の塩素の吸光 度の $\pm 5 \%$ 以内にあるとき，共存イオンの影響がない とみなした．水道水に含まれる主なイオンについて検討 し，許容共存イオン濃度の值を示す (Table 1)。 この 結果から当地に拉ける水道水中の共存イオンはこの定量 法の妨害とはならないことを示している.

Table 1 Effect of coexisting ions

\begin{tabular}{cl}
\hline Concentration (M) & \multicolumn{1}{c}{ Ion } \\
\hline $10^{-3}$ & $\mathrm{Na}^{+}, \mathrm{K}^{+}, \mathrm{HCO}_{3}{ }^{-}, \mathrm{SO}_{4}{ }^{2-}, \mathrm{Cl}^{-}$ \\
$5 \times 10^{-4}$ & $\mathrm{Ca}^{2+}, \mathrm{SiO}_{3}{ }^{2-}$ \\
$10^{-4}$ & $\mathrm{Mg}^{2+}$ \\
$10^{-5}$ & $\mathrm{NH}_{4}^{+}, \mathrm{HPO}_{4}{ }^{2-}, \mathrm{NO}_{3}^{-}$ \\
\hline
\end{tabular}

\section{7 塩素の揮散}

遊離塩素として，0.9 ppm を含む次亜塩素酸ナトリウ ムの水溶液を室温に打いて，フラスコ内に保存した場合 （密閉系）とビーカー内に保存した場合（開放系）の例 


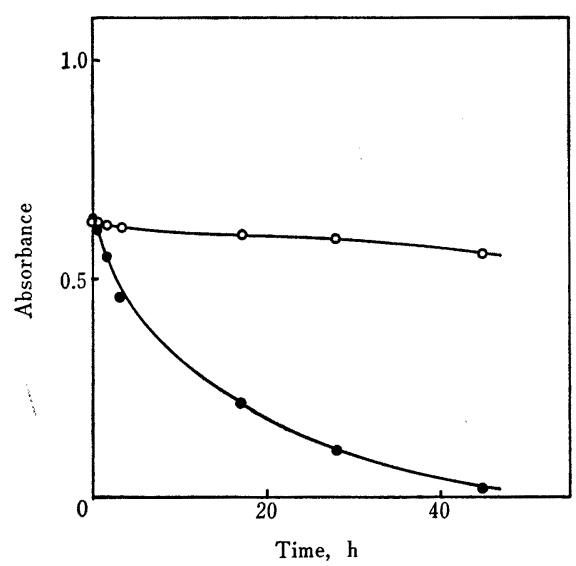

Fig. 3 Volatilization of chlorine in water $\mathrm{O}$ : Closed vessel; Open beaker

を Fig. 3 に示す. 開放系では時間とともに塩素が速や かに揮散してゆくことが分かる。

\section{5 応用}

岡山大学内の水道水中の残留塩素の定量結果を Table 2 に示す. Table 2 より, 建築年代が古いほど塩素が水 道鉄管の酸化に消費され，低い数值を示すことが判かっ た. 特に,塩素処理をした直後の水道局の水道水は 1.08 ppm と最も高い数值を示した.

Table 2 Analytical results of residual chlorine

\begin{tabular}{lllc}
\hline \multicolumn{1}{c}{ Sample } & Date & Absorbance & $\begin{array}{c}\mathrm{Cl}_{2} \\
\text { found } \\
\text { (ppm) }\end{array}$ \\
\hline Analytical Chemistry (1967) $\dagger$ & Feb. 27 & 0.172 & 0.23 \\
Faculty of Engineering (1968) & Feb. 27 & 0.407 & 0.58 \\
Faculty of Engineering (1968) & Mar. 4 & 0.375 & 0.54 \\
Geological Science (1970) & Feb. 27 & 0.429 & 0.62 \\
Geological Science (1970) & Feb. 27 & 0.436 & 0.63 \\
Geological Science (1970) & Mar. 4 & 0.416 & 0.60 \\
Faculty of Science No. 2 (1979) & Feb. 27 & 0.542 & 0.78 \\
Faculty of Science No. 2 (1979) & Feb. 27 & 0.502 & 0.72 \\
Faculty of Science No. 2 (1979) & Mar. 4 & 0.484 & 0.70 \\
Students Hall (1963) & Feb. 27 & 0.078 & 0.09 \\
Waterworks Bureau & Mar. 2 & 0.745 & 1.08 \\
\hline
\end{tabular}

$\dagger()$ indicates the construction year

$$
6 \text { フローインジェクション分析法 }
$$

残留塩素の $4,4^{\prime}$-ビスージメチルアミノーチオベンゾフ ェノンによる吸光光度定量法をフローインジェクション 分析法に応用した.

\section{$6 \cdot 1$ 装}

フローインジェクション分析装置を Fig. 4 に示す. $650 \mathrm{~nm}$ に拈ける吸光度を測定する．そのときのフロー セルはセル長 $10 \mathrm{~mm}$, 容量 $8 \mu \mathrm{l}$ であった.

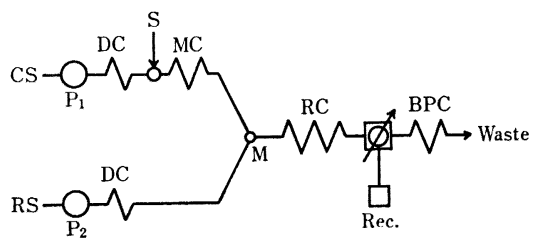

Fig. 4 Flow system

CS : Carrier solution; RS : Reagent solution; $\mathrm{P}_{1}(1.3$
$\mathrm{ml} / \mathrm{min}), \mathrm{P}_{2}(1.7 \mathrm{ml} / \mathrm{min}):$ Reciprocating pumps;
DC : Damper coil, $0.5 \mathrm{~mm} \phi \times 10 \mathrm{~m}$; $\mathrm{S}:$ Loop-valve
sample injector; $\mathrm{MC}:$ Mixing coil, $1 \mathrm{~mm} \phi \times 1 \mathrm{~m}$;
M : Mixing joint; RG : Reaction coil, $1 \mathrm{~mm} \phi \times 3 \mathrm{~m}$;
Rec : Recorder, $650 \mathrm{~nm}$; BPC : Back pressure coil,
$0.5 \mathrm{~mm} \phi \times 1 \mathrm{~m}$

\section{2 試 薬}

反応液 (RS) : 4, $4^{\prime}$-ビスージメチルアミノーチオベン ゾフェノン $40 \mathrm{mg}$, 濃塩酸 $0.5 \mathrm{ml}$ にエタノールを加え て全容を 11 とした．溶液は褐色瓶に入れて暗所に保存 し，使用前に沪過した後 $1 \mathrm{ml}$ のアセトンを加えて使用 した.

キャリヤー溶液 (CS) : 0.1 M ギ酸緩衝溶液 ( $\mathrm{pH} 3.5$ ) $950 \mathrm{ml}$ に $10^{-2} \mathrm{M}$ EDTA $50 \mathrm{ml}$, Triton X-405 の 1/ $500 \%(\mathrm{w} / \mathrm{v}) 2 \mathrm{ml}$ を加え，メンブランフィルター $(0.45$ $\mu \mathrm{m})$ で洰過して用いた。

\section{3 実験条件の検討}

吸光光度法と同じく $\mathrm{pH} 3.5 \sim 4.0$ で最高一定のピー ク高を示した. 又，そのときの空試験值も低かった。 $4,4^{\prime}$-ビスージメチルアミノーチオベンゾフェノンの濃度 は $0.04 \mathrm{~g} / 1$ のエタノール溶液のとき最高值を示し, 空 試験值も低かった. キャリヤー溶液の流速を $1.3 \mathrm{ml} /$ $\min$ としたとき，反応液の流速は $(1.7 \sim 1.8) \mathrm{ml}$ が最 もよく, 流速が遅くなると沈殿がチューブ内に付着しや すい.この際の沈殿の付着を防ぐために少量のアセトン を試薬溶液に加えた。サンプルループの長さを長くする ほど，すなわちサンプル量が多くなるほどピークの高さ は高くなる. しかし，空試験值も高くなる，そのため， 直径 $0.5 \mathrm{~mm}$, 長さ $100 \mathrm{~cm}$ のサンプルループを用い た. 共存イオンの影響について検討したが，岡山県下の 河川水に存在するイオンは妨害しない.しかし，カルシ ウムイオン及びマグネシウムイオンが $10^{-3} \mathrm{M}$ 以上存在 
すると妨害する．又，鉄イオンも妨害するので，古い水 道管から流出する水道水を考慮して EDTA を加宎, 妨 害を除去した.

\section{4 検量線}

前記組成の反応溶液及びキャリヤー溶液を用い，Fig. 4 亿示寸装置によって求めた検量線を Fig. 5 亿示した. 0 1.5 ppm の残留塩素に対してよい直線関係が得られ た.この装置に自動サンプリング装置を取り付けること で，水道水中の残留塩素を常時観測することが可能にな ると思われる。

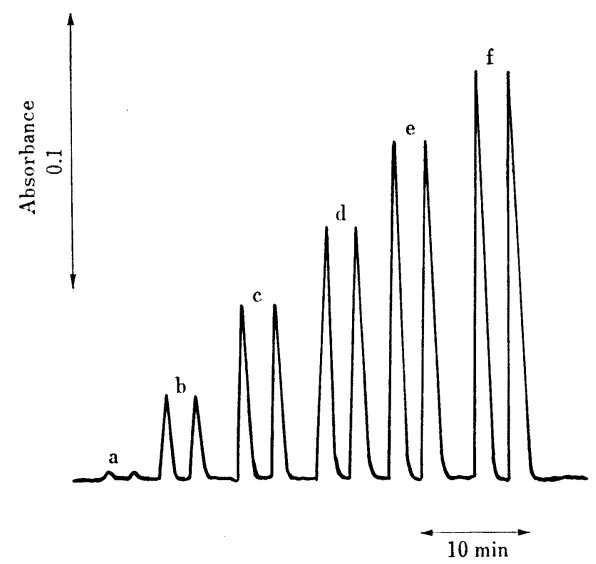

Fig. 5 FIA profiles

a : Blank; b : $0.3 \mathrm{ppm} ; \quad c: 0.6 \mathrm{ppm} ; \quad \mathrm{d}: 0.9 \mathrm{ppm}$; e : $1.2 \mathrm{ppm} ; \mathrm{f}: 1.5 \mathrm{ppm}\left(\mathrm{Cl}_{2}\right)$

\section{7 結語}

4, $4^{\prime}$-ビスージメチルアミノーチオベンゾフェノンを用 いる水道水中の残留塩素の吸光光度定量法を開発した.

又, この方法をつローインジェクション分析法に応用で きることを示した. この方法は簡便であるとともに，フ ローインジェクション分析法によって水道水中の塩素の 常時管理体制に貢献できるものと思われる.
本研究費の一部は日産科学振與財団からの研究助成金 によった・厚く謝意を表します。

\section{交献}

1)厚生省環境衛生局水道環境部監修：“上水試験法 1978 年版” p. 295 (1978), (日本水道協会).

2) Fritz Feigl : "Spot Tests in Inorganic Analysis", p. 368 (1958), (D. van Nostrand Co., Inc. New York).

3）高木誠司：“定量分析の実験と計算”，2, p. 353 (1960), (共立出版).

\section{is}

Determination of residual chlorine in city water by 4,4'-bis-dimethylamino-thiobenzophenone. Kyoji TôEI, Yoshie Ono, Toshiaki Wakiмото, and Haruo Mryata (Department of Chemistry, Faculty of Science, Okayama University, 3-1-1, Tsushima-naka, Okayama-shi, Okayama)

Gity water always contains $1 \mathrm{ppm}$ or less chlorine for sterilization. The residual chlorine was determined by Michler's thioketone (4,4'-bis-dimethylamino-thiobenzophenone) spectrophotometrically. City water (10 $\mathrm{ml}$ ) was mixed with $1 \mathrm{ml}$ of $0.2 \mathrm{M}$ acetate buffer solution ( $\mathrm{pH} 4$ ) and $5 \mathrm{ml}$ of Michler's thioketone solution which was prepared of $0.5 \mathrm{ml}$ of concentrated hydrochloric acid, $4 \mathrm{mg}$ of the ketone and $100 \mathrm{ml}$ of 1-propanol in a $25 \mathrm{ml}$ test tube with a ground stopper with shaking. After $10 \mathrm{~min}$ the absorbacne at 650 $\mathrm{nm}$ was measured in a $10 \mathrm{~mm}$ glass cell. The calibration graph showed a straight line which passed through the origin and the molar absorption coefficient was $7.65 \times 10^{4} \mathrm{dm}^{3} \mathrm{~mol}^{-1} \mathrm{~cm}^{-1}$. Coexisting cations and anions in city water in this district did not disturb the determination. The method was applied to flow injection analysis. The reaction solution contained $40 \mathrm{mg}$ of the reagent and $0.5 \mathrm{ml}$ of concentrated hydrochloric acid in 11 of ethanol, and the carrier solution was made of $950 \mathrm{ml}$ of $0.1 \mathrm{M}$ formate buffer solution ( $\mathrm{pH} 3.5$ ), $50 \mathrm{ml}$ of $0.01 \mathrm{M}$ EDTA and $2 \mathrm{ml}$ of $1 / 500 \%(\mathrm{w} / \mathrm{v})$ Triton $\mathrm{X}-405$. Each flow rate was 1.7 and $1.3 \mathrm{ml} / \mathrm{min}$, respectively. The peak height was proportional to the concentration of chlorine over the range of $0 \sim 1.5 \mathrm{ppm}$.

(Received Apr. 19, 1982)

\section{Keyword phrases}

spectrophotometry; flow injection analysis; residual chlorine; water analysis; 4,4'-bis-dimethylaminothiobenzophenone. 